THE ESSENTIALS OF MODERN SURGERY

Edited by R. M. HaNdField-Jones, M.C., M.S., F.R.C.S., and SIR ARTHUR E. PORRITT, K.C.M.G., C.B.E., M.Ch., F.R.C.S. 4th Edition. Pp. xv + 1263, with 64r illustrations, many in colour. Edinburgh: E. \& S. 'Livingstone. r95I. 55s.

'What surgery book shall I buy?' asks the student. Many practitioners cannot afford the time or money for volumes on the subdivisions that surgery has now split into. This book is certainly one of the best that embraces the whole subject. Beautifully produced and illustrated, it is easily read and its principles are thoroughly sound. Mr. Holmes Sellors has taken over the chapter on Chest Surgery, and Mr. J. F. Simpson those on Oto-Pharyngo-Laryngology.

A tree planted only I $_{3}$ years ago has little dead wood, but a certain amount of pruning would be apt. Pictures of thermos flasks to deliver saline seem hardly worth, their place, while the senior editor's crusade on infections of the hands needs some less painful first aid treatment of injuries than immersion in tincture of iodine for five minutes. The old long incisions for suppurative tenosynovitis of the hand are still figured, but penicillin irrigations are mentioned only in a final paragraph. The old word 'extension' is sporadically used for traction; being also the opposite of flexion, it causes confusion and might well be dropped. The advice given on treatment of an early case of congenital talipes equino-varus would give as poor a grasp of the child's foot as of Denis Browne's method of treatment. Manipulations are to be left to a capable nurse or masseuse correcting the deformity by numbers ' for a few seconds . . . at least three times a week.' This would do nothing but postpone proper treatment until a time when its best chance has been lost. Similarly, it is by no means generally agreed that every colostomy patient should irrigate and so spend 45 minutes each morning in attention to his bowel; or that radiotherapy for squamous-celled carcinoma of the anus should be reserved for inoperable cases. As a final protest, surely Halsted deserves correct spelling.

But these are small criticisms. The balance of the book is good and it presents a thoroughly readable, sound picture of the essentials of surgery. It is commended to all students.

\section{INFECTIVE HEPATITIS}

\section{M.R.C. Special Report, Series No. 273}

By F. O. MacCallum, M.D., B.Sc., et al. Pp. vi + 145. London: H.M.S.O. 1951. 4s. 6d.

The problem of epidemic jaundice is a constantly recurring one during war-time and the 1939-45 conflict was no exception. The wastage of manpower through infective hepatitis was so great that the Medical Research Council were requested to organize an investigation into all aspects of the disease. A team of experienced workers was gathered together and the results of their observations have now been published in the form of a Medical Research Council ' green book.'

The investigators were centred on Cambridge, and jaundice was made compulsorily notifiable in East Anglia for four years (1943-47). The epidemiology of infective hepatitis could thus be closely followed in this area. It was confirmed that young people are mainly affected, that the incubation period is 20 to 40 days and that spread is by contact through pharyngeal secretions or faeces. The most important biochemical finding was of bile in the urine before visible icterus. Sensitive tests for bile pigment in the urine were elaborated and proved useful for early diagnosis of the condition. Like their counterparts in the United States and elsewhere, the team had little luck in their efforts to find a diagnostic serological test.

No susceptible laboratory animals were discovered, but the serum and faeces of sufferers could transmit the disease to human volunteers. In the case of ' serum hepatitis,' only the serum proved infective and then only on parenteral administration. Sera from patients suffering from arsenotherapy jaundice could also transmit the disease when given parenterally to volunteers. This is conclusive evidence of the infective aetiology of this type of jaundice.

This is an excellent and authoritative report, well written and well produced. It can be thoroughly recommended to all those interested in infective hepatitis.

\section{THE KIDNEY: STRUCTURE AND FUNCTION IN HEALTH AND DISEASE}

By Homer W. Smith, A.B., Sc.D., M.S. Pp. xxii + ro49, with 153 illustrations. New York: Oxford University Press (London: Geoffrey Cumberlege). 1951. $£ 5$.

Fifteen years ago a new and remarkable book appeared, one of a number of monographs devoted to physiology published by the Oxford University Press. That was 'The Physiology of the Kidney,' by Homer Smith. It struck at least one reader with the force of a revelation, not only on account of its contents but by the sheer lucidity of its style and the reasoned presentation of its facts. It embodied the first results of the author's work on renal function, and it stimulated countless workers all over the world. How fruitful that stimulus has been can be judged from the present work, with its 2,300 references, a large number of which are to the direct results of the technical methods introduced by the author.

This book is, of course, an encyclopaedia, a vast storehouse of information, excellently arranged and readily available. As far as the kidney is concerned it is the encyclopaedia, for no other book contains anything like the same amount of information about the subject. To every worker in this field it will be literally indispensable.

Faced with such a magnum opus the reviewer may be forgiven for a feeling of dismay, for recoiling 